Available online at: http://ejournal-balitbang.kkp.go.id/index.php/iaj

\title{
GROWTH AND EXPRESSION PATTERN OF GROWTH-RELATED GENES IN THE FAST-GROWING GIANT GOURAMI Osphronemus goramy
}

\author{
Siska Aliyas Sandra, Hasan Nasrullah, Harton Arfah, Muhammad Zairin Jr., and Alimuddin\# \\ Department of Aquaculture, Faculty of Fisheries and Marine Sciences, Bogor Agricultural University \\ Jl. Agatis, Dramaga Campus, Bogor 16680, West Java, Indonesia
}

(Received: March 9, 2021; Final revision: July 14, 2021; Accepted: July 14, 2021)

\begin{abstract}
Growth improvement of the giant gourami through molecular assisted selection offers a breakthrough solution regarding the slow growth problem in culturing the fish species. However, gene molecular expression studies and gene mapping information are scarce for this species. This study aimed to evaluate the growth, expression of the growth-related genes and compare the gene expressions between fast-growing $(\mathrm{FG})$ and slow-growing (SG) fish. The polymorphism screenings were also conducted within the GH sequence of the FG and SG populations. Fish growth was analyzed by measuring length and weight once a month. The expression levels of GH, IGF1, AMPK, ARS-I, ALT, and AST genes were analyzed using real-time PCR. Twentyfive days old fish were reared for 30 days. The fish were continuously reared separately based on their body weight (BW) for 85 days until reaching 140 days old. At the end of the rearing period, the BW growth rate of the FG population was 1.569-fold higher, and body length (BL) growth was 1.056-fold higher than the SG population. FG fish have higher gene expression than the SG fish, indicating the important role of gene expression in fish growth. The polymorphisms screening within the $\mathrm{GH}$ sequences showed no significant difference between FG and SG fish of giant gourami. These research results provide valuable information in developing the marker-assisted selection for growth traits in giant gourami.
\end{abstract}

\section{KEYWORDS: gene expression; GH-IGF1 axis; giant gourami; growth; polymorphism}

\section{INTRODUCTION}

Giant gourami (0. goramy Lacapede 1801) is a freshwater fish species native to Indonesia. Giant gourami belongs to the Anabantiformes order, in which betta fighting fish Betta spp., dwarf gourami Trichogaster spp., and paradise fish Macropodus spp. are also the members. Giant gourami is mainly cultured and harvested as traditional food, highly valued due to its pleasant flavor, and highly demanded in the domestic market (Arifin et al., 2019; Slembrouck et al., 2018). However, giant gourami has a slower growth rate compared to other aquaculture species (Arifin et al., 2018; Setijaningsih et al., 2007), thus affecting its production time and cost. Conventional breeding programs of giant gourami have been implemented in Indonesia based on crossing and hybridization between strains (Arifin et al., 2017, 2018; Sularto et al., 2016). However, conventional breeding programs take con-

\# Correspondence: Department of Aquaculture, Faculty of Fisheries and Marine Sciences, Bogor Agricultural University. Jl. Agatis, Dramaga Campus, Bogor 16680, West Java, Indonesia E-mail: alimuddin@ apps.ipb.ac.id siderable time and effort to optimize the fish growth characteristics (Gjedrem \& Rye, 2016). In recent years, researchers have moved toward genotype and molecular-based selections for the aquaculture breeding program (Robinson et al., 2014; Shen et al., 2016). Improvement of the growth through conventional breeding programs integrated with molecular tools is considerably faster and more accurate. It also allows understanding the possible genetic mechanisms behind the faster growth rate in the particular fish species (Xu et al., 2017; Yue, 2013).

Most study has focused on the growth hormone (GH)/insulin-like growth factor-1 (IGF1) axis, which is central in regulating fish somatic growth to find the potential markers for better growth (Allard \& Duan, 2018; Berenjkar et al., 2018; Gilannejad et al., 2020; Li et al., 2017). GH was secreted from the pituitary and binds to its receptors on target tissues (Triantaphyllopoulos et al., 2020). The GH binding to its receptors will stimulate the expression and secretion of IGF1, activating the anabolic signaling and promoting fish growth (Fuentes et al., 2013; Triantaphyllopoulos et al., 2020). Insulin receptor 
substrate-1 (IRSI) also plays a key role in transmitting signals from the insulin and IGF1 receptors to the intracellular mitogen-activated protein kinase (MAPK) pathways (Copps \& White, 2012; Sun et al., 1991). The cascade is accompanied by glucose uptake, which leads to the increased activity of metabolic and growth promotion (Fuentes et al., 2013). The 5 ' adenosine monophosphate-activated protein kinase (AM P-activated protein kinase; AM PK) was also related to the growth promotion. It stimulates hepatic fatty acid oxidation, glucose uptake, and modulation of insulin secretion by pancreatic beta-cells (Copps \& White, 2012; Matschinsky, 2002). In fish, AMPK is reported to maintain cellular energy and promotes catabolic pathways to provide energy (Causey et al., 2019; Sanchez-Gurmaches et al., 2012). The expression of these genes has been reported to be related to the better growth rate in several fish species (Gilannejad et al., 2020; Mun et al., 2019). Aside from its expression levels, the polymorphisms of growth-related genes such as GH and IGF-1 gene were also reported to be related to the better growth in fish such as in common carp (Berenjkar et al., 2018), Atlantic salmon (Tsai et al., 2014), and Chinese perch (Tian et al., 2014).

Currently, the lack of molecular expressions and gene mapping information for molecular markers is the key limiting factor in the realization of genotype-based selection in giant gourami. The information about the expression evaluation of the potential genes related to growth traits in giant gourami is scarce. The genetic polymorphism mapping, especially for the $\mathrm{GH}$ gene of this species, was also limited. Thus, this study was aimed to evaluate the growth, expression of the growth-related genes and compare the expressions between fast-growing (FG) and slow-growing (SG) giant gourami. The potential polymorphisms screening was also conducted within the GH gene sequence of the FG and SG fish.

\section{MATERIALS AND METHODS}

\section{Fish and Rearing}

The experiment was conducted from August 2020 to January 2021. Twenty-five days old giant gourami were obtained from a local farm in Sukabumi, West Java, Indonesia. The fish came from the same batch of mass spawning of five pairs of brood fish and were carefully monitored since hatching. Fish were reared indoor for 30 days in $120 \mathrm{~L}$ glass tanks ( $n=3,000$; 500 fish/tank) equipped with a pump-filter, moderate aeration, and a heater installed at $28^{\circ} \mathrm{C}$. The tanks were shrouded in black cover to reduce the stress.
Fish were fed with freeze-dried worms thrice daily with the same amount ( $12 \%$ BW/day) at every tank until 40 days old. Worms were minced into smaller pieces then distributed equally into the tanks. Commercial feed (39\%41\%protein) was given three times a day at satiation at 40-55 days old. Waste was removed daily, and $50 \% 60 \%$ water change was conducted every three days. After a month, the fish were weighed to obtain the bodyweight distribution for separating the fish into FG and SG groups.

FG fish were taken from the population that had $20 \%$ highest BW, while SG fish were $20 \%$ fish with the lowest BW. Both groups were reared separately in a 1 $\mathrm{m} \times 1 \mathrm{~m} \times 1 \mathrm{~m}$ hapa inside outdoor concrete tanks with a density of 100 fish $\mathrm{m}^{-2}$. The hapas were covered with a lid as the shade to reduce stress. The tanks were set with a running water system and moderate aeration. The fish were fed with a commercial feed (39\%41\%protein) at satiation three times a day and reared until 85 days old. During the rearing period, the temperature, dissolved oxygen (DO), pH, total ammonia nitrogen (TAN), and nitrite were maintained between $27.7^{\circ} \mathrm{C}-33.5^{\circ} \mathrm{C}, 5.2-8.8 \mathrm{mg} \mathrm{L}{ }^{-1}, 7.19$ $8.21,<0.1 \mathrm{mg} \mathrm{L}^{-1}$, and $0.19-0.31 \mathrm{mg} \mathrm{L}^{-1}$, respectively. At 85 days old, FG and SG fish were transferred separately into $2 \mathrm{~m} \times 4 \mathrm{~m} \times 1.2 \mathrm{~m}^{3}$ hapas (50 fish $\mathrm{m}^{-2}$ ) inside the outdoor HDPE-lined (high-density polyethylene) ponds. The fish were reared until 140 days old and fed with a commercial feed (39\%41\%protein) at satiation three times a day. During the rearing period, the temperature, $\mathrm{DO}, \mathrm{pH}, \mathrm{TAN}$, and nitrite were maintained between $31.5^{\circ} \mathrm{C}-33.2^{\circ} \mathrm{C}$, 5.6-8.4 $\mathrm{mg} \mathrm{L}^{-1}$, $7.39-8.19,<0.2 \mathrm{mg} \mathrm{L}^{-1}$, and $0.098-0.121 \mathrm{mg} \mathrm{L}^{1}$, respectively. Fish survival was monitored daily.

\section{Fish Sampling and Tissues Isolation}

Fish body weight (BW) and body length (BL) were measured at $55,85,110$, and 140 days old to obtain the fish growth performance. Fish grading at 55 days old was conducted in three batches. Six hundred fish were measured in each batch. At 85 days old, the growth of two hundred fish from each group were measured before transferring them into the hapa. At 110 and 140 days old, only thirty fish were sampled from each group to prevent the excess stress that might disrupt the growth of the fish. Before each sampling process, the fish were anesthetized using 1 $\mathrm{mL} \mathrm{L}^{-1}$ of commercial fish stabilizer. For gene expression analysis, forty fish from FG and SG group at 55 days old were randomly separated. The fish were fasted for $24 \mathrm{~h}$ before re-feeding. Tissue samples of fish pituitaries and livers from each group were isolated before re-feeding and 3 and 6 hours after re- 
feeding ( $n=3$ each time points). The fish were euthanized before each tissue isolation. Fish tissues were stored inside the Genezol reagent (Genaid, Taiwan) at $-80^{\circ} \mathrm{C}$ before analysis. All research procedures related to the fish were complied with the animal welfare guideline and approved by the Ethical Committee of IPB University with permit No. 185-2020IPB.

\section{RNA Extraction and Expression Analysis}

Total RNA was extracted from the fish tissues using Genezol reagent, following the product manual. RNA concentration was measured at 260 and $280 \mathrm{~nm}$ using spectrophotometry. The RNA integrity was evaluated using $1 \%$ gel agarose electrophoresis. The first-strand cDNA synthesis was carried out using ReverTraAceqPCR RT Master Mix with gDNA Remover (Toyobo, Japan) from $1 \mu \mathrm{g} \mathrm{mL}^{-1}$ total RNA and purified using DNAse treatment. A quantitative real-time polymerase chain reaction ( $q P C R$ ) method was conducted to analyze the gene expression of the growth-related gene. The genes evaluated in this study were $\mathrm{GH}$, IRS1, IGF1, and AMPK. $\beta$-actin gene was used as the internal control. Each gene's primers used in the qPCR analysis are presented in Table 1 . The reaction was carried out inside the $200 \mu \mathrm{L}$ sterile PCR tubes (ExtraGene, Taiwan) consisted of $10 \mu \mathrm{L}$ SensiFAST SYBR NO-ROX mix (Bioline, UK), $0.8 \mu \mathrm{L}$ of each qPCR primers $(10 \mathrm{mM}), 4.4 \mu \mathrm{L}$ of sterile nucleases free water ( $1^{\text {st }}$ base, Malaysia), and $4 \mu \mathrm{L}$ of $\mathrm{cDNA}\left(25 \mathrm{ng} \mu \mathrm{L}^{-1}\right)$. All molecular procedures were carried out using filtered microtips (ExtraGene, Taiwan) to prevent contamination. The qPCR reaction was run in Rotor-Gene 6000 machine (Corrbet, USA) with a reaction program as follows: 2 min of holding time at $95^{\circ} \mathrm{C}$, continued with $40 \mathrm{cycles}$ of $95^{\circ} \mathrm{C} 10 \mathrm{sec}$, annealing temperature (Ta) $15 \mathrm{sec}$, and $72^{\circ} \mathrm{C} 15 \mathrm{sec}$. The program was ended with a melting curve analysis to evaluate the reaction specificity.

\section{Sequencing of GH Gene}

Caudal fins from FG and SG fish were collected when the fish were 85 days old. DNA was extracted from the fin using the Puregene Core Kit A (Qiagen, USA) following the kit's instructions. The GH sequence was amplified using PCR with the sets of primers which amplified the exon 1"exon 3, and exon 33'UTR (untranslated region) of the GH genes. The primer sequences are presented in Table 1 . The reaction was carried out inside the $200 \mu \mathrm{L}$ sterile PCR tubes (ExtraGene, Taiwan) using MyTaqHS Enzyme Red Mix (Bioline, UK) with a total volume reaction of 50 $\mu \mathrm{L}$. The quality and specificity of the PCR products were evaluated with the $1 \%$ gel electrophoresis method. The verified PCR products ( $n=23$ for each group) were sent to the $1^{\text {st }}$ base laboratory (Selangor, Malaysia) to be sequenced. Sequencing results were aligned in MEGAX software (megasoftware.net). Gene polymorphisms were assessed manually from the aligned sequence.

\section{Data and Statistics}

Fish growth rates from FG and SG populations were compared using one-way ANOVA followed by Duncan's posthoc test $(p=0.05)$. The relative gene expression data were analyzed using the comparative method (Livak \& Schmittgen, 2001) after normalized using the $\beta$-actin gene. The gene expressions were comparable to the expression before re-feeding (expression at $0 \mathrm{~h}=1$ ) in the corresponding group. The gene expression data comparison between FG and SG fish were conducted using the Independent t-test $(p=0.05)$. GH gene polymorphisms were assessed and described descriptively based on the aligned sequencing data.

\section{RESULTS AND DISCUSSION}

The gene approach discussed in this study is a very powerful method to investigate associations of gene expression and polymorphism with the growth trait in fish species. To our knowledge, this is the first report that studies the gene expression pattern related to the fast-growing fish and analyzes the polymorphism of the $\mathrm{GH}$ gene in giant gourami. This study separated the giant gourami into the fast-growing (FG) and slow-growing (SG) groups based on their body weight distribution and reared them separately for 85 days.

The average body weight and its distribution at 55 days old fish are presented in Figure 1. The fish population had an average BW of $0.24 \pm 0.67 \mathrm{~g}$. The $20 \%$ highest weight was distributed at 0.19-0.61 g, while the lowest was $0.01-0.16 \mathrm{~g}$. The fish were then grouped as FG and SG according to their weight and reared separately for 85 days until reaching 140 days old (Figure 1). FG fish constantly possessed a higher average BW than the SG fish $(p<0.05)$. However, SG fish tend to have a broader distribution in line with the rearing periods while FG fish BW distribution was relatively constant.

The body weight and length pattern of fast growth and growth of giant gourami are presented in Figure 2. The pattern showed that FG fish consistently had higher BW and BL compared to the SG fish since they were reared separately. However, the growth variation increased in line with the fish age and rearing 
Table 1. Lists of primer used in this study

\begin{tabular}{|c|c|c|c|}
\hline Primer name & Sequence (5'-3') & $\operatorname{Ta}\left({ }^{\circ} \mathrm{C}\right)$ & Application \\
\hline $\begin{array}{l}\text { qGH F } \\
q G H R\end{array}$ & $\begin{array}{c}\text { CTCAGATTACATCATCAGCCCTATC } \\
\text { CTTTGAGCAGAACCTCCATACA }\end{array}$ & 57 & qPCR analysis of GH gene \\
\hline $\begin{array}{l}\text { qIGF1 F } \\
\text { qIGF1 R }\end{array}$ & $\begin{array}{l}\text { CTGTATCTTCTGTAGCCACACC } \\
\text { CCTCTCTCTCCACACACAAAC }\end{array}$ & 60 & qPCR analysis of IGF1 gene \\
\hline $\begin{array}{l}\text { qIRS1 F } \\
\text { qIRS1 R }\end{array}$ & $\begin{array}{l}\text { GGCAGGCAGTGACTATATGAA } \\
\text { GGGCTTGCTGTTGAGAACTA }\end{array}$ & 60 & qPCR analysis of IRS1 gene \\
\hline $\begin{array}{l}\text { qAMPK F } \\
\text { qAMPK R }\end{array}$ & $\begin{array}{l}\text { GATGTCAGATGGAGAGTTCCTG } \\
\text { CACCTCTGGACCAGCATATAAC }\end{array}$ & 60 & qPCR analysis of AMPK gene \\
\hline $\begin{array}{l}\text { qACTB F } \\
\text { qACTB R }\end{array}$ & $\begin{array}{l}\text { ACCGGAGTCCATCACAATACCAGT } \\
\text { GAGCTGCGTGTTGCCCCTGAG }\end{array}$ & 60 & Internal control and expression normalizer \\
\hline $\begin{array}{l}\text { Ex1-GHF } \\
\text { Ex3-GHR }\end{array}$ & $\begin{array}{l}\text { ATGGACAAAGTTGTGTTCCTGCTG } \\
\text { GTCGATAGGGCTGATGATGTAATC }\end{array}$ & 65 & Sequencing of exon 1-3 GH gene \\
\hline $\begin{array}{l}\text { EX3-GHF } \\
\text { 3UTR-GHR }\end{array}$ & $\begin{array}{l}\text { GAGAGCTCCTTGCAGACTG } \\
\text { CATGTACTGACAGTGTGACATC }\end{array}$ & 65 & Sequencing of exon 3-3'UTR GH gene \\
\hline
\end{tabular}

period, shown by the value of the standard deviation line.

A comparison of growth performance between FG and SG fish is presented in Table 2. At the initial separation, FG fish had 3.888-fold of BW and 1.516-fold of BL higher than SG. After reared separately for 85 days, FG still had higher BW and BL than SG (1.706-fold and 1.196-fold, respectively). At the end of the rearing period, the BW growth rate of FG fish was 1.569-fold higher, and BL growth was 1.056-fold higher than SG. No significant difference in fish survival was observed at the end of the experiment.

The FG fish had a higher growth rate compared to SG throughout the rearing period. The growth performance of FG showed that the specific growth rate (SGR) was $14.302 \% B W /$ day. Another study showed that the highest SGR of giant gourami was 3.19\%BW/ day (Samuki et al., 2020).

The gene expression comparison of growth-related genes between FG and SG fish is presented in Figure 3. IRS1 was significantly higher three hours after feeding $(p<0.05)$, while IGF1 was higher after six hours post-feeding $(p<0.05)$. The $\mathrm{GH}$ expression was rapidly and had higher expression in FG fish $(p<0.05)$. However, at later hours, $\mathrm{GH}$ expression was higher in SG fish. In line with other genes, AMPK expression was also significantly higher in FG fish at both 3 and 6 hours after feeding $(p<0.05)$.

Growth is a polygenic and environmentally regulated trait, with GH and IGF1 being the most important genes (Gomez et al., 1999; Triantaphyllopoulos et al., 2020). The expressions of GH and IGF1 were observed to be rapidly and highly modulated in the FG fish compared to the SG fish of giant gourami. The expression magnitude of GH and IGF1 has been influenced by various stimuli such as developmental process (age), stress, diet, and environment condition (Gilannejad et al., 2020; Malandrakis et al., 2016; Triantaphyllopoulos et al., 2020). However, FG and SG fish were reared with the same density, age, strains, and culture conditions. This study indicated that the difference in gene expression occurred due to the differences in the gene regulation between $F G$ and SG fish. A previous study showed that IGFBP1 and GHR2 can be used for fast growing fish markers in grass carp family (Lu et al., 2020). Those genes may also potentially be utilized in future works as the molecular markers of fast-growing giant gourami.

Higher expression of GH-IGF1 genes was also reported to potentially trigger other gene expression cascades. Upon receiving the signals from IGF1 receptor (IGF1R) and insulin after re-feeding, IRS1 was transmitting the signals to intracellular mitogen-activated protein kinase (MAPK) to promote glucose uptake (Copps \& White, 2012; Fuentes et al., 2011; Sun et al., 1991). IGF1, together with adenosine monophosphate-activated protein kinase (AM PK), will also activate the target of rapamycin (TOR) pathways that will lead to increased protein synthesis and muscle growth (Fuentes et al., 2013). In FG fish, IRS1 and AMPK expressions were significantly increased and higher than that of the SG after re-feeding. These results suggest that the fast-growing fish gained their 

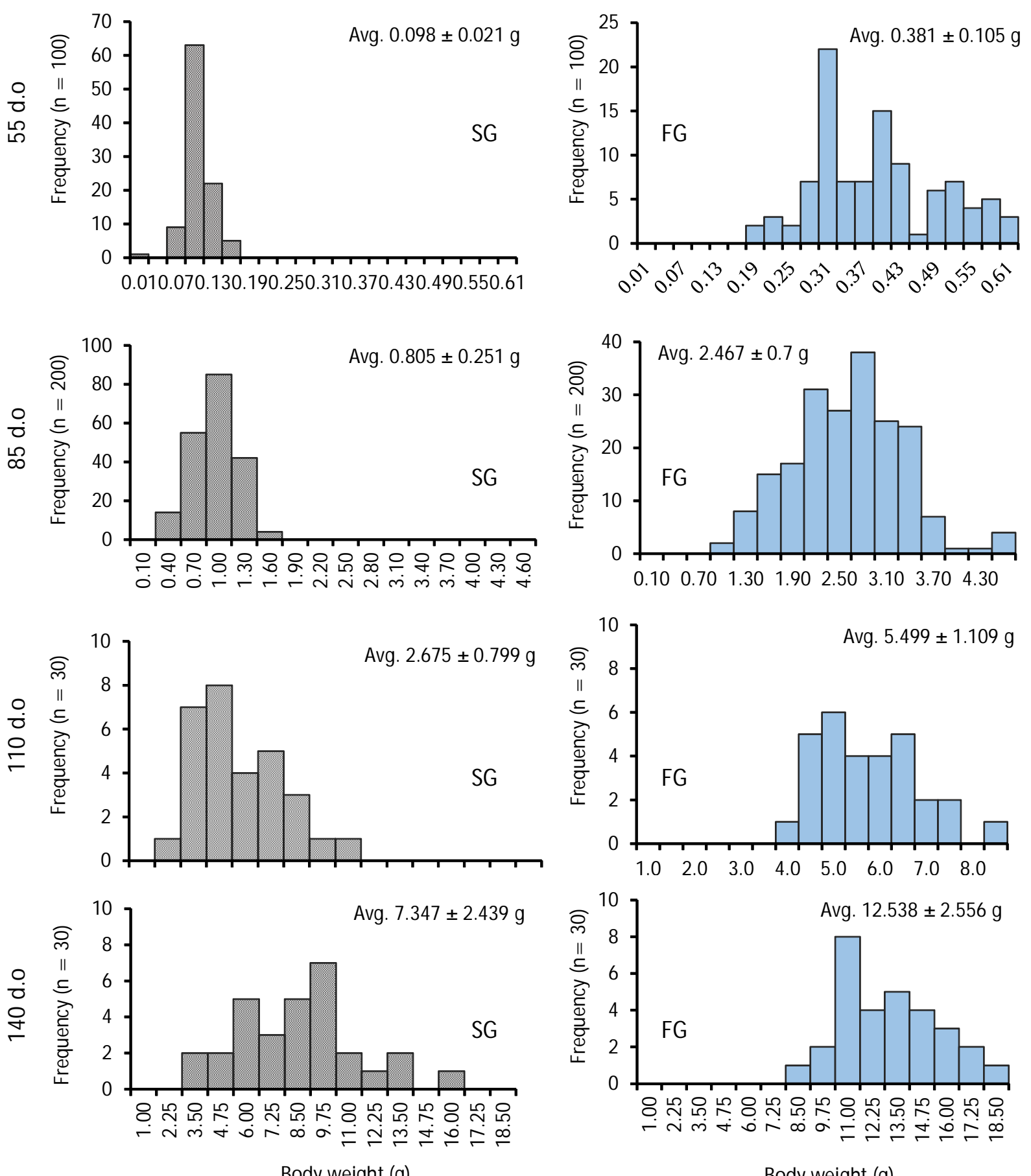

Figure 1. Body weight (BW) distribution of fast growth (FG) and slow growth (SG) population of giant gourami at $55,85,110$, and 140 days old. FG and SG fish were reared separately since 55 days old according to their respective bodyweight.

faster growth rate due to their better regulation at their GH-IGF1 axis-related genes and the IRS1 and AMPK roles that promote nutrient uptake and maintain energy utilization. The present results also showed that the IGF1 expression was lower than GH, especially in SG fish after re-feeding. GH levels in SG fish remained high six hours after re-feeding in contrast with the IGF1 level that was remained low. IGF1 expressions in $\mathrm{FG}$ were also lower than in $\mathrm{GH}$, but still higher than SG at the same time points after refeeding. This imbalance of the GH-IGF1 ratio indicated the inherent impairment of the $\mathrm{GH}$ system in this species. This imbalance was hypothesized to be responsible for the slow growth as reported in fine flounder Paralichthys adsperus (Fuentes et al., 2012). In fine flounder, the inherent GH resistance was characterized by higher levels of plasma GH than that of IGF-I, greater levels of the truncated GH receptor 

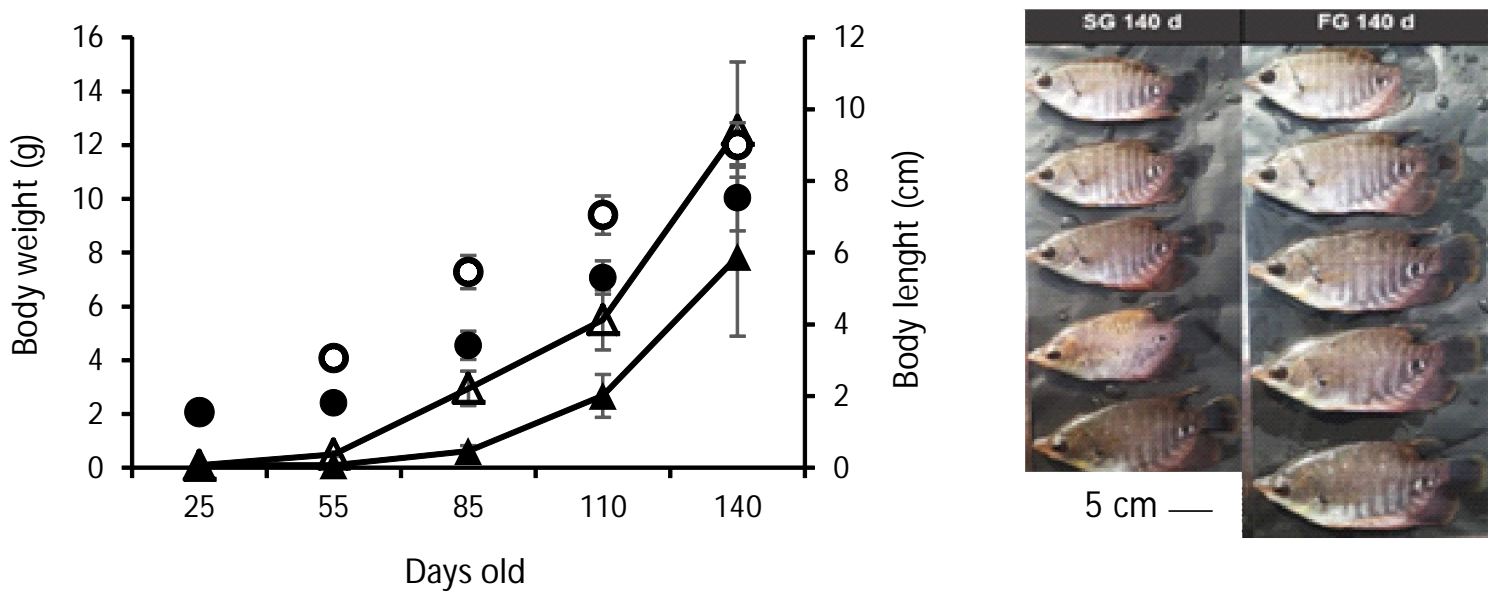

Figure 2. Body weight and length pattern of fast growth and slow growth of giant gourami. Body length was marked with circle symbols ( $\bullet$ and o), and body weight was marked with the line with triangle symbols ( $\boldsymbol{\Delta}$ and $\Delta$ ). FG fish was indicated by white-colored symbols (o or $\Delta$ ), while black indicated the SG fish (• or $\mathbf{\Delta})$. Data were presented as mean $\pm \mathrm{SD}$. However, the SD line is not presented in certain time points due to its smaller size than the marker symbols. Figure on the right is the difference in the size of the 140-day-old FG dan SG fish.

Table 2. Growth performance of a fast-growing and slow-growing populations of giant gourami Osphronemus goramy

\begin{tabular}{lcccc}
\hline \multicolumn{1}{c}{ Parameters } & Unit & FG & SG & $\begin{array}{c}\text { Fold change } \\
\text { (FG vs SG) }\end{array}$ \\
\hline $\mathrm{BW}_{55}$ & $\mathrm{~g}$ & $0.381 \pm 0.105^{\mathrm{a}}$ & $0.098 \pm 0.021^{\mathrm{b}}$ & 3.888 \\
$\mathrm{BW}_{140}$ & $\mathrm{~g}$ & $12.539 \pm 2.556^{\mathrm{a}}$ & $7.348 \pm 2.439^{\mathrm{b}}$ & 1.706 \\
$\mathrm{BL}_{55}$ & $\mathrm{~cm}$ & $2.992 \pm 0.235^{\mathrm{a}}$ & $1.973 \pm 0.226^{\mathrm{b}}$ & 1.516 \\
$\mathrm{BL}_{140}$ & $\mathrm{~cm}$ & $9.033 \pm 0.618^{\mathrm{a}}$ & $7.553 \pm 0.922^{\mathrm{b}}$ & 1.196 \\
\hline SGR-BW & $\%$ dday & 14.302 & 9.117 & 1.569 \\
GR-BW & g/day & 0.143 & 0.091 & \\
\hline SLG-BL & \%dday & 7.072 & 6.698 & 1.056 \\
LG-BL & cm/day & 0.07 & 0.067 & 0 \\
Survival & $\%$ & 92.72 & 92.72 & 0 \\
\hline
\end{tabular}

Note: Different superscripted letters indicated a significant difference between the fast-growing $(F G)$ and the slow-growing (SG) population. $\mathrm{BW}_{55}=$ initial body weight at 55 days old, $\mathrm{BW}_{140}=$ final body weight at 140 days old. $\mathrm{BL}_{55}=$ initial body length at 55 days old, $\mathrm{BL}_{140}=$ final body length at 140 days old, $\mathrm{SGR}=$ specific growth rate for $B W, G R=$ growth rate for $B W, S L G=$ specific body length growth, $L G=$ body length growth

(GHRt) than of full-length GHR (GHRfI), and low IGFI mRNA expression (Fuentes et al., 2012). However, this phenomenon could not be explained in this present study. Future research regarding this phenomenon should be conducted to understand the nutritional and growth mechanism in giant gourami.

Multiple sequence alignments of the $\mathrm{GH}$ gene sequences from the FG and SG populations of giant gourami are presented in Figure 4. The exon 1-3 amplified region covered about 490 nucleotides, and the exon 3-3'UTR region covered 1,108 nucleotides. The aligned sequencing results showed no significant polymorphic sequences of $\mathrm{GH}$ sequence between FG and SG population of giant gourami.

The polymorphisms screening resulted in no significant difference within the $\mathrm{GH}$ sequence of $\mathrm{FG}$ and 


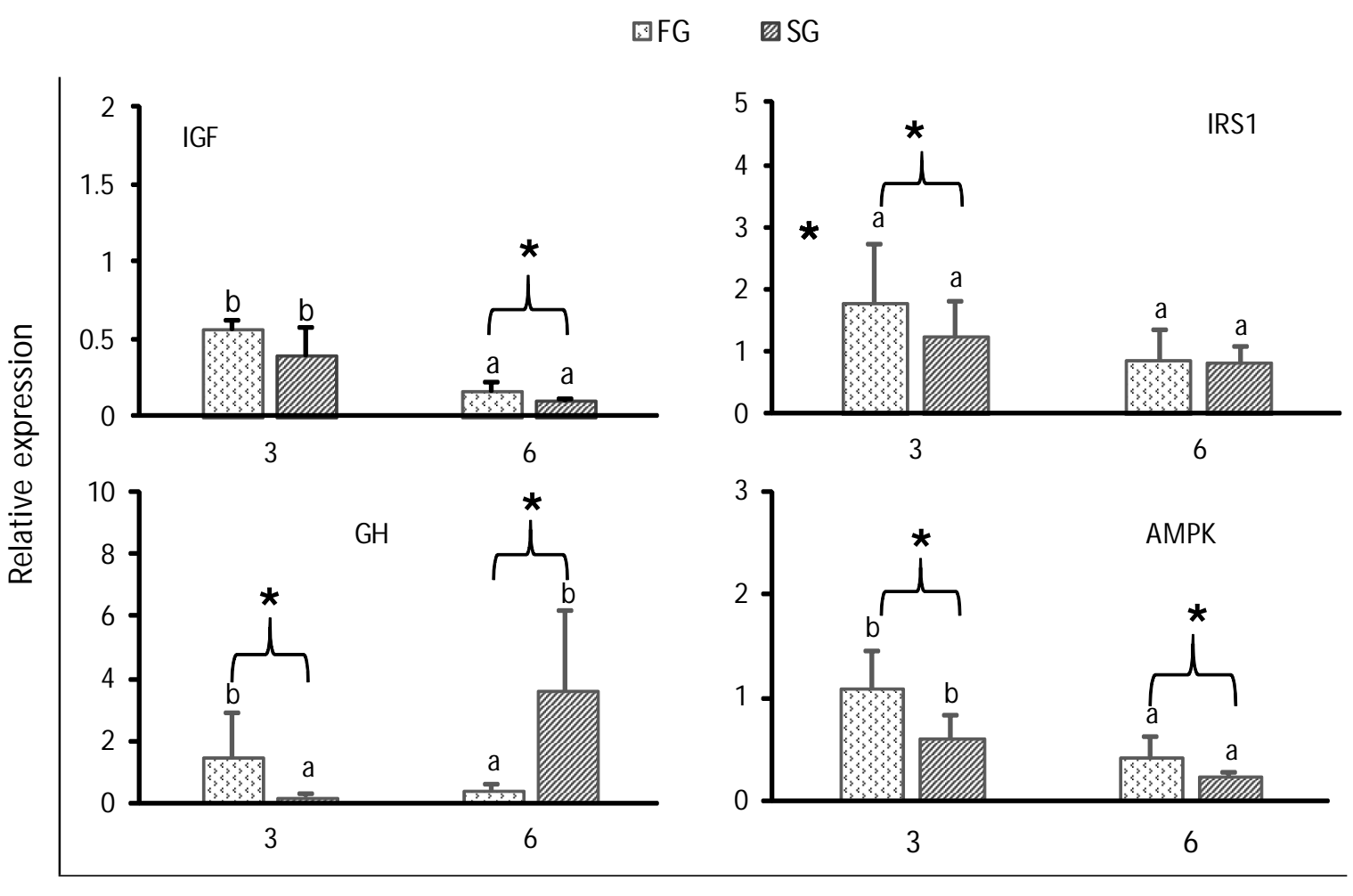

Hours after re-feeding

Figure 3. The comparison of growth-related gene expression of the fast-growing and slow-growing populations of giant gourami. Different letters indicate a significant difference in the same population at different time points $(p<0.05)$. Asterisks $(*)$ indicate a significant difference between FG and SG $(p<0.05)$. Data presented as mean expression $\pm S D$ $(n=3)$.

SG fish. In other fish species, single nucleotide polymorphisms (SNPs) in GH genes were detected and correlated with fish growth. In Chinese perch Siniperca chuatsi, two mutations in intron 4, one mutation in exon 5 , and one in intron 5 were found in the $\mathrm{GH}$ gene sequences and significantly associated with growth performance (Tian et al., 2014). Five SNPs and four microsatellites (SSRs) were identified in the GH gene of yellow catfish Pelteobagrus fulvidraco, with two SNPs in intron 4, and one mutation in the 3'UTR that were significantly associated with growth traits ( $\mathrm{Li}$ et al., 2017). These results indicated that the $\mathrm{GH}$ gene of giant gourami might be less polymorphic than other fish species despite this claim requires further observation. Other regions such as the promoter and 5 '-UTR region of $\mathrm{GH}$, and the genomic sequence of IGF1, IRS1, and AMPK could potentially be further explored to find the potential polymorphisms as the molecular marker related to the faster growth trait in giant gourami. The results proved that GH, IGF1, IRS1, and AMPK have higher genes expressions in FG fish than SG fish. In striped catfish Pangasianodon hypopthalmus, SNP IGF1 in intron 2 and IGFIR in in- tron 15 significantly associated with growth trait (Tran et al., 2021). Microsatellite DNA markers showed that four genotypes were assosiated with the growth trait of P. hypopthalmus (Marnis et al., 2018). Even though there is no significant difference within the GH sequence of FG and SG fish, the result opens up for future investigation on larger size fish and different culture environments.

\section{CONCLUSION}

The fast-growing population of giant gourami has a higher growth rate than the slow-growing population after reared separately for 85 days. FG fish has higher GH, IGF1, IRS1, and AMPK gene expressions than the SG fish indicating the genes expression important roles for the fish growth. As such, it is argued that these genes could responsible for the faster growth trait within the FG population. The polymorphisms screening in the $\mathrm{GH}$ sequences resulted in no significant difference within the GH sequence of $F G$ and SG fish in giant gourami. The result from the present study suggest that open up for future investigation on promoter and 5'-UTR region of GH gene. 


\section{Exon 3-6}
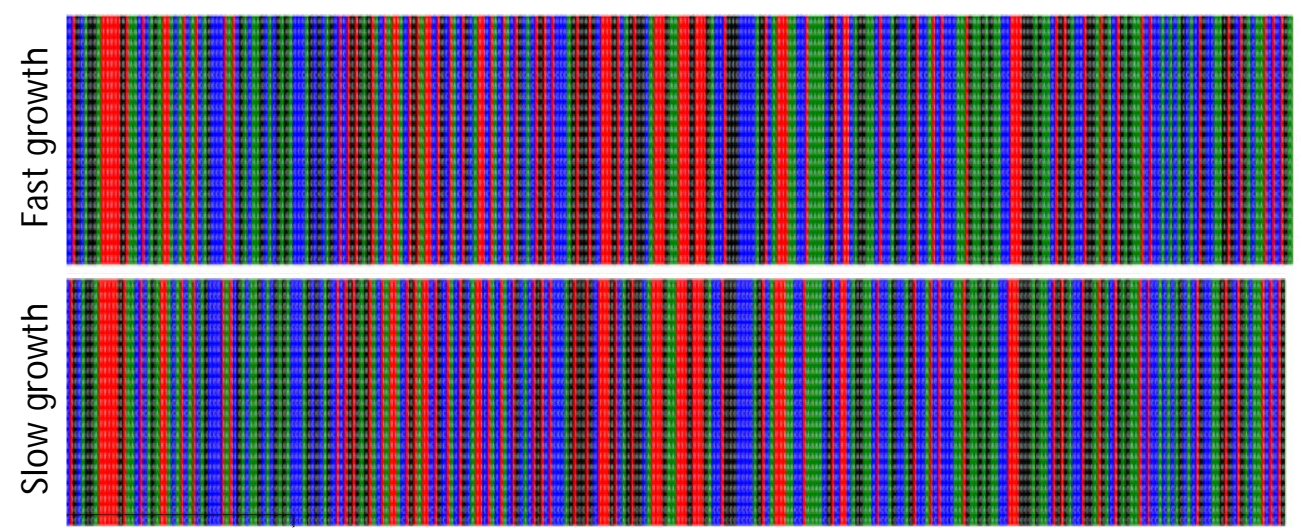

Exon 3-6
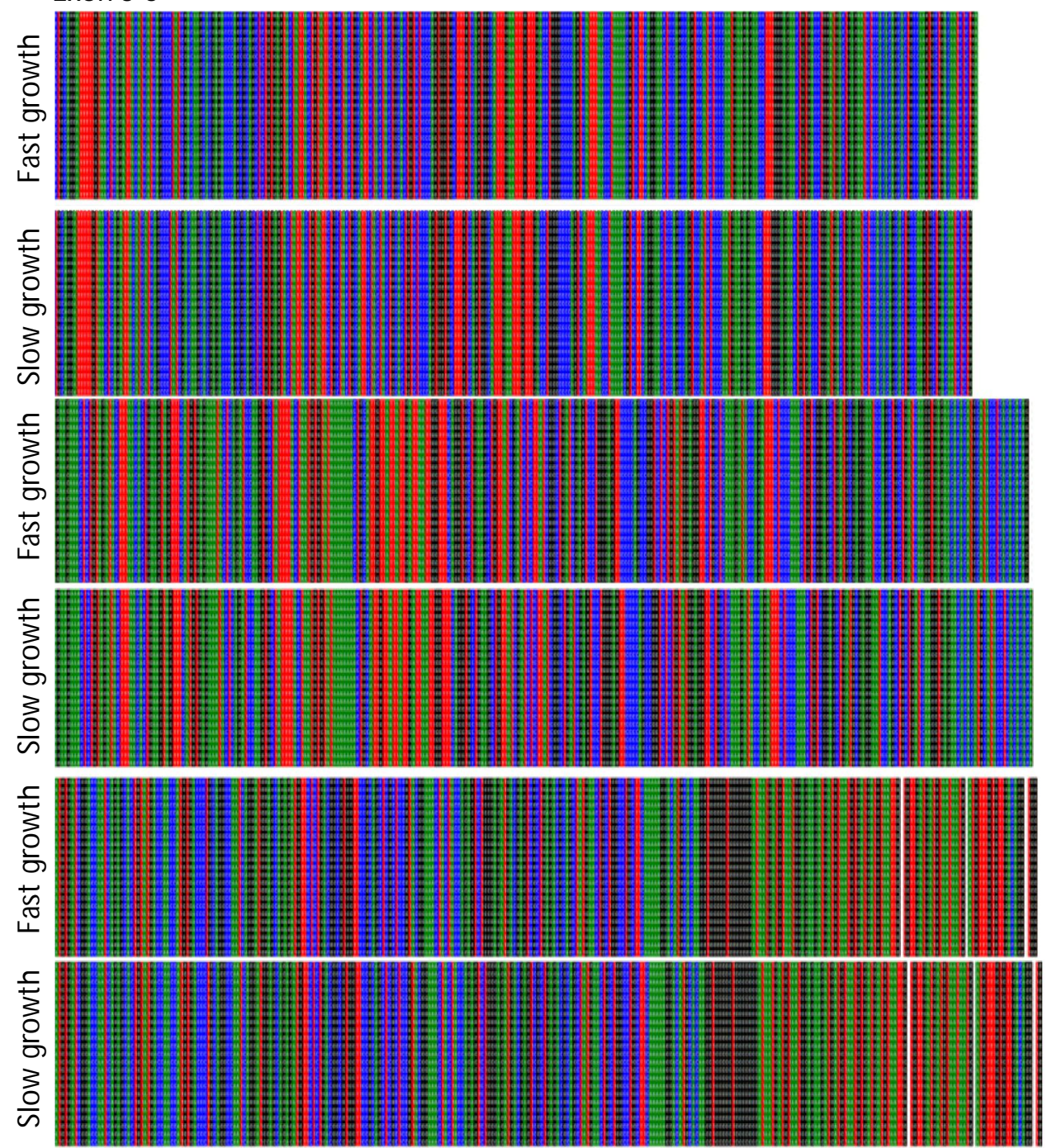

Figure 4. Multiple alignments of the $\mathrm{GH}$ gene sequence from the fast-growing and slow-growing populations of giant gourami. The alignment was conducted using the ClustalW program from FG and SG fish $(n=23$ each group). Row 1-23 is FG, and 24-46 is SG. Green represents adenine, black for guanine, blue for cytosine, and red for thymine. No significant polymorphisms were found between FG and SG. 
The future research may on larger size fish and different culture system.

\section{ACKNOWLEDGMENTS}

This research was funded by the Ministry of Research and Higher Education of the Republic of Indonesia under Magistrate Thesis Grant [No. 1/AMD/E1/ KP.PTNBH/2020] for A. Alimuddin and S.A Sandra. The author thanks Ms. Dian Novita Sari (Department of Aquaculture, IPB University) for offering advice on the qPCR assays and providing the qPCR primers; $\mathrm{Mr}$. Dedi Supriyadi and Mrs. Lina Mulyani (Department of Aquaculture, IPB University) for their excellent help in the laboratory works and fish rearing.

\section{REFERENCES}

Allard, J.B. \& Duan, C. (2018). IGF-binding proteins: Why do they exist and why are there so many? Frontiers in Endocrinology, 9, 1-12. https://doi.org/ 10.3389/fend0.2018.00117.

Arifin, 0.Z., Imron, I., Asependi, A., Hendri, A., Muslim, N., \& Yani, A. (2018). Intra-specific hybridization between two populations of Galunggung giant gourami (Osphronemus goramy Lacepede, 1801). Jurnal Riset Akuakultur, 12(4), 315. https://doi.org/ 10.15578/jra.12.4.2017.315-323.

Arifin, 0.Z., Imron, I., Muslim, N., Hendri, A., Aseppendi, A., \& Yani, A. (2017). Phenotypic and genotypic characteristic of black Galunggung, white-Galunggung and its hybrid strains of giant gourami Osphronemus goramy. Jurnal Riset Akuakultur, 12(2), 99. https://doi.org/10.15578/ jra.12.2.2017.99-110.

Arifin, 0.Z., Prakoso, V.A., Subagja, J., Kristanto, A.H., Pouil, S., \& Slembrouck, J. (2019). Effects of stocking density on survival, food intake and growth of giant gourami (Osphronemus goramy) larvae reared in a recirculating aquaculture system. Aquaculture, 509(February), 159-166. https://doi.org/ 10.1016/j.aquaculture.2019.05.010.

Berenjkar, N., Khalesi, M.K., RahimiMianji, G., \& Farhadi, A. (2018). Association between growth hormone gene polymorphisms and growth traits in wild common carp, Cyprinus carpio from the Caspian Sea. Iranian Journal of Fisheries Sciences, 17(3), 533-541. https://doi.org/10.22092/ IJFS.2018.116471.

Causey, D.R., Kim, J.H., Stead, D.A., Martin, S.A.M., Devlin, R.H., \& Macqueen, D.J. (2019). Proteomic comparison of selective breeding and growth hormone transgenesis in fish: Unique pathways to enhanced growth. Journal of Proteomics, 192, 114124. https://doi.org/10.1016/j.jprot.2018.08.013.

Copps, K.D. \& White, M.F. (2012). Regulation of insulin sensitivity by serine/threonine phosphorylation of insulin receptor substrate proteins IRS1 and IRS2. Diabetologia, 55(10), 2565-2582. https:// doi.org/10.1007/s00125-012-2644-8.

Fuentes, E.N., Björnsson, B.T., Valdés, J.A., Einarsdottir, I.E., Lorca, B., Alvarez, M., \& Molina, A. (2011). IGF-I/PI3K/Akt and IGF-I/M APK/ERK pathways in vivo in skeletal muscle are regulated by nutrition and contribute to somatic growth in the fine flounder. American Journal of Physiology-Regulatory, Integrative and Comparative Physiology, 300(6), R1532-R1542. https://doi.org/10.1152/ ajpregu.00535.2010.

Fuentes, E.N., Einarsdottir, I.E., Valdes, J.A., Alvarez, M., Molina, A., \& Björnsson, B.T. (2012). Inherent growth hormone resistance in the skeletal muscle of the fine flounder is modulated by nutritional status and is characterized by high contents of truncated GHR, impairment in the JAK2/STAT5 signaling pathway, and low IGF-I expression. Endocrinology, 153(1), 293-294. https://doi.org/10.1210/ en.2011-1313.

Fuentes, E.N., Valdés, J.A., Molina, A., \& Björnsson, B.T. (2013). Regulation of skeletal muscle growth in fish by the growth hormone: Insulin-like growth factor system. General and Comparative Endocrinology, 192, 136-148. https://doi.org/10.1016/ j.ygcen.2013.06.009.

Gilannejad, N., de lasHeras, V., Martos-sitcha, J.A., Moyano, F.J., Yufera, M., \& Martinez-Rodriguez, G. (2020). Ontogeny of expression and activity of digestive enzymes and establishment of gh/igf1 Axis in the omnivorous fish chelonlabrosus. Animals, 10, 1-20. https://doi.org/10.3390/ ani10050874.

Gjedrem, T. \& Rye, M. (2016). Selection response in fish and shellfish: A review. Reviews in Aquaculture, p. 1-12. https://doi.org/10.1111/raq.12154.

Gomez, J.M., Weil, C., Ollitrault, M., Bail, P. Le, Breton, B., \& Gac, F.Le. (1999). Growth hormone (GH) and gonadotropin subunit gene expression and pituitary and plasma changes during spermatogenesis and oogenesis in rainbow trout (Oncorhynchus mykiss). General and Comparative Endocrinology, 428, 413-428.

Li, M.J., Liu, W.S., Luo, W., Zhang, X.Q., Zhu, W.L., Wang, J., Liao, L.Y., \& Li, G.H. (2017). Polymorphisms and their association with growth traits 
in the growth hormone gene of yellow catfish, Pelteobagrus fulvidraco. Aquaculture, 469, 117-123. https://doi.org/10.1016/j.aquaculture.2016.11.028.

Livak, K.J. \& Schmittgen, T.D. (2001). Analysis of relative gene expression data using real-time quantitative PCR and the $2-\Delta \Delta C T$ method. Methods, 408(25), 402-408. https://doi.org/10.1006/ meth.2001.1262.

Lu, X., Chen, H., Qian, X., \& Gui, J. (2020). Comparative biochemistry and physiology: Part $D$; Transcriptome analysis of grass carp (Ctenopharyngodon idella) between fast- and slowgrowing fish. Comparative Biochemistry and Physiology - Part D, 35, 100688. https://doi.org/10.1016/ j.cbd.2020.100688.

Marnis, H., Tahapari, E., \& Darmawan, J. (2018). Correlation of microsatellite DNA markers with growth traits in striped catfish (Pangasianodon hypophthalmus). Indonesian Aquaculture Journal, 13(2), 51-56. https://doi.org/10.15578/ iaj.13.2.2018.51-56.

Malandrakis, E.E., Dadali, O., Golomazou, E., Kavouras, M., Dailianis, S., Chadio, S., Exadactylos, A., \& Panagiotaki, P. (2016). DNA damage and differential gene expression associated with physical stress in gilthead seabream (Sparus aurata). General and Comparative Endocrinology, 236, 98-104. https://doi.org/10.1016/j.ygcen.2016.07.009.

Matschinsky, F.M. (2002). Regulation of pancreatic âcell glucokinase. Diabetes, 51(Suppl. 3), S394-S404.

Mun, S.H., You, J.H., Oh, H.J., Lee, C.H., Baek, H.J., Lee, Y.-D., \& Kwon, J.Y. (2019). Expression patterns of growth related genes in juvenile red spotted grouper (Epinephelus akaara) with different growth performance after size grading. Development \& Reproduction, 23(1), 35-42. https://doi.org/ 10.12717/dr.2019.23.1.035.

Robinson, N.A., Gopikrishna, G., Baranski, M., Katneni, V., Shekhar, M.S., Shanmugakarthik, J., Jothivel, S., ..... \& Ponniah, A.G. (2014). QTL for white spot syndrome virus resistance and the sexdetermining locus in the Indian black tiger shrimp (Penaeus monodon). BMC Genomics, 15(1), 731. https://doi.org/10.1186/1471-2164-15-731.

Sanchez-Gurmaches, J., Cruz-Garcia, L., Gutierrez, J., \& Navarro, I. (2012). Adiponectin effects and gene expression in rainbow trout: an in vivo and in vitro approach. Journal of Experimental Biology, 215(8), 1373-1383. https://doi.org/10.1242/jeb.061697.

Samuki, K., Setiawati, M., Jusadi, D., \& Suprayudi, M.A. (2020). The evaluation of á -Lipoic acid supplementation in diet on the growth performance of giant gourami (Osphronemus goramy) juvenile. Aquaculture Research, p. 1-10. https:// doi.org/10.1111/are.15006.

Setijaningsih, L., Arifin, Z.O., \& Gustiano, R. (2007). Characterization of three strains of giant gourami Osphronemus gouramy Lac. using the truss-morphometric method. Jurnal Iktiologi Indonesia, 7(1), 23-30.

Shen, X., Ngoh, S.Y., Thevasagayam, N.M., Prakki, S.R.S., Bhandare, P., Tan, A.W.K., Tan, G.Q., ....., \& Orbán, L. (2016). BAC-pool sequencing and analysis confirms growth-associated QTLs in the Asian seabass genome. Scientific Reports, 6, 1-13. https:/ /doi.org/10.1038/srep36647.

Slembrouck, J., Arifin, 0.Z., Pouil, S., Subagja, J., Yani, A., Kristanto, A.H., \& Legendre, M. (2018). Gender identification in farmed giant gourami (Osphronemus goramy): A methodology for better broodstock management. Aquaculture. https:// doi.org/10.1016/j.aquaculture.2018.08.056.

Sularto, S., Febrianti, R., \& Suharyanto, S. (2016). The estimation of heritability and the selection responses in the giant gourami crosses population (Osphronemus goramy Lac.). Jurnal Riset Akuakultur, 11(1), 23. https://doi.org/10.15578/ jra.11.1.2016.23-28.

Sun, X.J., Rothenberg, P., Khan, C.R., Backer, J.M., Araki, E., Wilden, P.A., Cahill, D.A., Goldstein, B.J., $\&$ White, M.F. (1991). Structure of the insulin receptor substrae IRS-1 defines a unique signal transduction protein. Nature, 354, 56-58.

Tian, C., Yang, M., Lv, L., Yuan, Y., Liang, X., Guo, W., Song, Y., \& Zhao, C. (2014). Single nucleotide polymorphisms in growth hormone gene and their association with growth traits in Siniperca chuatsi (Basilewsky). International Journal of Molecular Sciences, 15(4), 7029-7036. https://doi.org/10.3390/ ijms15047029.

Tran, T.T.H., Nguyen, H.T., Le, B.T.N., Tran, P.H., Van Nguyen, S., \& Kim, O.T.P. (2021). Characterization of single nucleotide polymorphism in IGF1 and IGF1R genes associated with growth traits in striped catfish (Pangasianodon hypophthalmus Sauvage, 1878). Aquaculture, 538, 736542. https:// doi.org/10.1016/j.aquaculture.2021.736542.

Triantaphyllopoulos, K.A., Cartas, D., \& Miliou, H. (2020). Factors influencing GH and IGF-I gene expression on growth in teleost fish: How can aquaculture industry benefit?. Reviews in Aquaculture, 12(3), 1637-1662. https://doi.org/10.1111/ raq. 12402. 
Tsai, H.Y., Hamilton, A., Guy, D.R., \& Houston, R.D. (2014). Single nucleotide polymorphisms in the insulin-like growth factor 1 (IGF1) gene are associated with growth-related traits in farmed Atlantic salmon. Animal Genetics, 45(5), 709-715. https:/ /doi.org/10.1111/age.12202.

Xu, Y., Li, P., Zou, C., Lu, Y., Xie, C., Zhang, X., \& Prasanna, B.M. (2017). Enhancing genetic gain in the era of molecular breeding. Journal of Experimental Botany, 68(11), 2641-2666. https://doi.org/ 10.1093/jxb/erx135.

Yue, G.H. (2013). Recent advances of genome mapping and marker-assisted selection in aquaculture. Fish and Fisheries, p. 1-21. https://doi.org/10.1111/ faf.12020. 